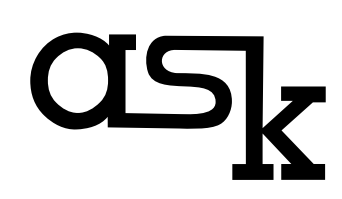

Research \& Methods ISSN 1234-9224, e-ISSN 2544-0799 Vol. 28 (1, 2019): 61-80 The Ohio State University Libraries Columbus, Ohio, USA Institute of Philosophy and Sociology Polish Academy of Sciences, Warsaw, Poland www.askresearchandmethods.org https://doi.org/10.18061/ask.v28i1.0004

\title{
Exploratory Fieldwork on Balconies as Threshold Spaces on the Juliusz Słowacki housing estate in Lublin
}

\author{
Natalia Otrishchenko \\ The Center for Urban History of East Central Europe, Lviv, Ukraine
}

\begin{abstract}
The author reflects upon her experience of exploratory fieldwork conducted by an interdisciplinary group during the Urban Summer School. The research was conducted within an environment built according to the idea of "Open Form", introduced by architect Oskar Hansen. Together with his wife Zofia, he designed a few neighborhoods around Poland, one of which - the Juliusz Słowacki housing estate in Lublin - is used as a case study for this paper. The article follows the process of collaborative development of research design and discusses a number of methods (focused ethnography, interviews, mental mapping, observation, participatory photography) applied to the study of materiality and social functioning of balconies as "threshold spaces" and their domestication. The author also outlines her positions in relation to both the local people with whom she has conducted interviews about their homes and the participants of her group.
\end{abstract}

Key words: ethnography; fieldwork; interview; mental mapping; observation; research design; threshold spaces.

\section{INTRODUCTION}

A red cat slowly stepped out between the railings. He was leaving the balcony on the ground floor in one of the buildings on Balladyny Street, ironically referred as "The Great Wall of China." As I was following the cat, a lady called him. I met Anna ${ }^{1}$ and her cat, Citek, and it was the beginning of my exploration of the Juliusz Słowacki housing estate in Lublin during the "Urban Summer School: Open 
Form"2 - an educational and research initiative, which was designed as a platform for communication among early-stage researchers with diverse backgrounds, not only in terms of their academic studies but also in language, country of origin, educational and professional trajectories.

The subject of the Urban Summer School 2018 was related to the development of the "Open Form" idea introduced by Oskar Hansen (1922-2005), an architect and educator from Team X, who worked together with his wife, Zofia GarlińskaHansen (1924-2013). This concept was their attempt to confront hierarchical and inflexible urban planning practices and to create an environment which is jointly formed by both architects and inhabitants. In those 60 years since the couple developed this idea and put it into practice a number of political, economic, social, and cultural transformations have taken place, both in Poland and in larger contexts. How is "open form" now reflected in different urban settings and on different scales?

Participants of Urban Summer School were expected to develop research projects in relation to the space of the Juliusz Słowacki housing estate in Lublin, designed according to the "open form" idea. They worked in three studios following the scales that were developed by the Hansens - the micro scale of personal spaces, the meso scale of the estate's community, and the macro scale of connections to the larger structures - the city and the state. However, the topic of specific interest for each group, as well as the selection of appropriate methodology, collection of materials, method of analysis, and format of presentation, was up to the collaborative decision of the group participants. Consequently, the participants were involved in every stage of the research process during the course of the summer school: from the setting of common questions to the framing of the final results. Together with Tomasz Fudala, art historian and curator at the Museum of Modern Art in Warsaw, I was tutoring the micro studio. Tomasz provided expertise on the work of the Hansens, and my responsibilities included providing methodological support and facilitating the fieldwork, as it was related to my sociological background. The paper is a reflection on this experience. I am going to outline the specifics of my numerous positions (in relation to my group and local people), discuss the key challenges connected both to the general framework of the summer school and specific group constellation, and give an overview of some of the findings from the field related to the materiality of the "extended home" - the balcony. However, I would like to start with a note on the concept of "open form" and then proceed to my case study on the balconies of the Juliusz Słowacki housing estate. 


\section{DISCUSSING THE OPENNESS OF "OPEN FORM”}

The idea of "open form" was introduced in 1956 and elaborated in 1961 in the "Open Form Manifesto" by Oskar and Zofia Hansen. The authors believed that "[the] Open Form, unlike the Closed Form, ${ }^{3}$ does not exclude the energy of the client's initiative but on contrary treats it as a basic, organic, and inseparable component element ... [and] is aid to the individual in finding himself in the collective, to make him indispensable in the creation of his own surroundings" (Hansen and Hansen [1961] 2014: 7 - 8). It aims to free human creativity, given that everyone is part of a particular group that does not limit as much as it provides opportunities. According to this concept, architects in their practice have to focus on specific people with specific needs rather than "average" ones, and as a result, the open form reflects a "sum of individualities of a given group" (Ibidem: 9). It is especially important with regard to the planning of mass housing, which was intended to provide accommodation for a large number of people.

Somehow this idea was "in the air" when Hansen put it into words. Modernist urban planning started to be questioned both by people without an academic background in this field ${ }^{4}$ and by the community of architects, especially representatives of younger generations. Inside the professional milieu of urban planners such critical remarks were formulated by Team X, or Team Ten - the informal group, which was organized within CIAM (Congrès Internationaux d'Architecture Moderne) during the 1940s and 1950s. ${ }^{5}$ Giancarlo De Carlo, who was in "the inner circle" of Team X, claimed that "architecture is too important to be left to architects" ([1969] 2007: 13), and similar ideas were expressed by architect Bernard Rudofsky on the other side of the Atlantic (1964). Both supported the vision of active inhabitants and the delegation of power from the architects to the users of architecture, so that the role of the artist changed from conceptional to more mediatorial. Such ideas marked shifts in the professional discourse with an emphasis on planning for people and with people.

Lukasz Stanek and Dirk van den Heuve outlined three common concepts that were seriously discussed by Team X: "openness," "greatest number," and "participation" (2014: 25-28). Oskar Hansen, who was himself a member of this group, took part in this intellectual debate and reflected on all of these ideas in his architectural and didactic practice. However, the "Eastern" wing of Team X (see Stanek 2014) - i.e., Karoly Polónyi, Jerzy Sołtan, and Oskar Hansen experienced quite a different reality compared to their colleagues from "the West": they had to work under the conditions of state socialism, with both its limitations and possibilities. For instance, Hansen's professional practice took place in postwar Poland, which was experiencing the challenges of reconstruction, extensive urbanization, political, economic, and social experiments and, later, mass-housing 


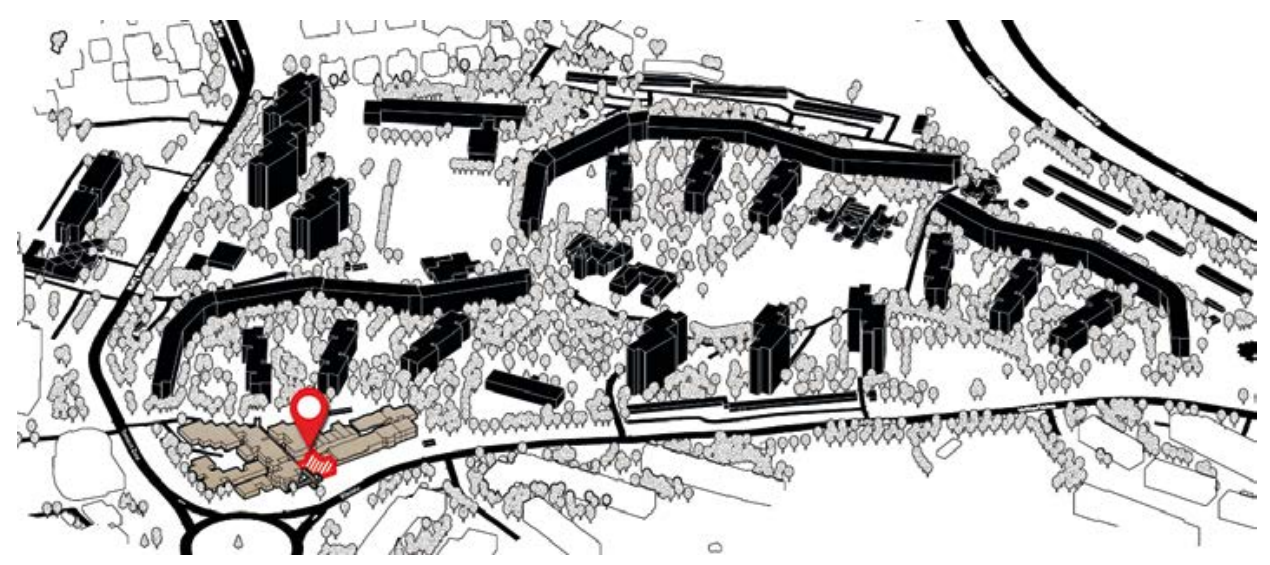

Figure 1. The Juliusz Słowacki estate with the location of the Muzeum Osiedli Mieszkaniowych (Museum of Housing Estates). Image: Iwona Drewniak (2019)

programs (see Coudroy de Lille 2013; Crowley 2002). Moreover, one of the reasons why he as a young and promising architect returned to Poland from his studies abroad was "his eagerness to rebuild the country" (Sulikowska 2015: 97).

Hansen had a possibility to put some of his ideas into practice on the scale of housing estates - he planned Przyczółek Grochowski (1963) and Rakowiec (1964) estates in Warsaw and the Juliusz Słowacki estate in Lublin (1964 - 1966) (Odyjas 2014: 130). The last project was used as the primary case for our urban summer school (Figure 1). It was designed and constructed to accommodate people who were moving to Lublin, which became an industrial and scientific centre of Eastern Poland after the Second World War. The estate was built during the post-Stalinist period, when "the politics of the Thaw encouraged new kinds of thinking about the housing, if not necessarily the home" (Crowley 2002: 193). Industrial production of prefabricated panel buildings had to provide an alternative to overpopulated communal apartments, dormitories or rural huts. New mass housing was intended to be the incarnation of a socialist future, a symbol of progress and modernity, a counterargument to the dark narrow streets of the old cities. However, it also produced a uniform environment, often with cheap materials and ill-conceived spatial solutions. According to Hansen's plan, the Juliusz Słowacki housing estate had to become the antithesis of typical block constructions and demonstrate the fruitfulness of the cohabitation of a great number of people. Though he had to work in a specific place (the socialist Polish People's Republic) and during a specific time (the rule of Władysław Gomułka, 1956-70), his original ideas were modified in the process of realization, mainly due to the lack of financial resources. One of the aims of the summer school program was to examine the incarnation of "open 
form" on different scales - from one apartment to the whole neighborhood (while acknowledging the discrepancies between the concept and the implementation) and to see how it is adopting to the post-socialist context and what challenges it is facing.

\section{SETTING THE STAGE FOR A COLLABORATIVE PROJECT}

Each studio was composed of people with different educational, professional and cultural backgrounds. ${ }^{6}$ With such a diverse group of young professionals, who usually were not trained anthropologists or sociologists, we had to negotiate a "common language," agree on methods, and dig into ethnographic reality (which could be quite different from our own, as we came from different regions) - all in just two weeks. None of us had worked in Lublin before (for some people it was their first visit to Poland, or even to Central Europe), and only three of us could speak Polish. This meant we had to outline not only our preferences, but also the constraints we faced. Even though there was enthusiasm for focusing mainly on conversations with locals, it was almost impossible to do this face-to-face, and the very situation of translation led to the loss of immediacy. Furthermore, at least half of the group had no experience in conducting interviews (and more generally, were not familiar with anthropological and sociological methods). Acknowledging these constraints at the very beginning was crucial for shaping our research questions.

While mapping our competences and trying to work out common ground, we outlined three topics that were simultaneously related to the topic of our studio and to our interests. The first one was directly related to "The Open Form Manifesto," as we were concerned about "recognizing concrete people - not the abstract so-called 'average"" (Hansen and Hansen [1961] 2014: 7) who are the current population of the Juliusz Słowacki housing estate (in terms of their age, gender, occupation, lifestyle, economic status, type of ownership, place of origin, etc.). We wanted to expand our analysis to both humans and non-humans, like pets or birds. Nevertheless, this topic was too ambitious, taking into account the discussed constraints and available resources of time. The next topic changed the emphasis from people to spaces: the intention was to analyze what spaces inhabitants use within their apartments in relation to different purposes, different temporalities, and in different social constellations (individually, with family members, with guests). In this context we mentioned spaces in between "private" and "public" and "border spaces" as possible interest points and discussed the potential of Hansen's "active negative" concept - " inventory" of impressions from the space" (Gola 2005: 105-106) - as a research tool. The last topic was related to the process of changes, as modification of the environment by active users is at the core of the "Open Form" approach - what parts of the house were changed, by whom, 
why, how and with what resources. All three topics were interrelated, and it was possible to narrow down the last two into specific cases, while the first one was too broad. However, with these topics in mind, we started a preliminary exploration of the Juliusz Słowacki housing estate: unstructured observations, flaneur walking, photo documentation of the buildings' surfaces and short chats with local people. Being outsiders was to some extent beneficial as we were perceived as a neutral party who was not involved in conflicts between stakeholders (like those between the administration of the estate and activists). As information about the school was present in the media, local people generally knew about us and were willing to help. Last but not least, badges distinguished us from other people - we were "marked" from the very beginning of the fieldwork, and it was impossible to blend in with the environment.

In order to access the private realities of people, we decided to use a method which was not mediated by language-mental mapping. It was applied to the groups of children who participated in a summer camp called "Open Form. The Estate Project" - an educational initiative for local children organized in parallel with the urban summer school. We visited one of the meetings of this program and asked the children to draw their apartments. There were no specific guidelines on how and what to draw; therefore, some children created something like ground plans, while others depicted rather separate "boxes" of rooms. This task was performed with a mutual exchange of experience - children, participants of our studio, coordinators of this educational program, and me all together made drawings of our homes and subsequently answered the same list of questions. Examples of such questions were: Who do you live with? What is your favorite room and why? Which room do you dislike and why? These clarifications were meant to be a framework for further analysis. During this Q\&A session I played the role of interpreter from Polish into English, as I was translating the answers of children to participants of my studio (and their follow-up questions back to the children).

Overall, the maps were drawn by seven children (aged 9-12) who were participants of the summer camp. Furthermore, we asked them to do "homework" with their parents and to bring their pictures the next day. It was a methodological challenge to formulate a task in a way that the pictures could be analyzed without talking to their authors. Thus, we decided to use prescribed colors for different routes inside the apartment and pictograms to mark places with certain meanings. As a result, the task that the children had to convey to their parents was the following: "Please draw your apartment. Mark your everyday routes: on working days with blue, on weekends with red. Mark your favorite places with hearts. Mark places where you can be alone with triangles. Mark places where the family gathers with circles. Mark places where you meet guests with stars." Also, we asked parents for background information, including age, gender, occupation, and 
how long they had lived in the apartment. In this way, we received four additional drawings.

At this stage, the research was developing in breadth - we were probing the reality of home with different methods in order to understand what amount if of work is manageable in such a short period of time. The issue of uncertainty was the main challenge during these first days, because the studio participants were not quite sure about the direction of the study and expected results. As tutors we had to refrain from giving our own ready-made solutions and did not impose our own visions. This situation created some tension when students waited for guidance from us, and we provided only a framework for discussion. A certain level of psychological discomfort was somewhat intensified after the preliminary exploration phase, when we had already collected some material and were struggling to formulate the questions. Furthermore, our idea to study the transformation of the spaces was also restricted by language, as it meant we had to interview people about the changes they had made in their apartments. The main topic of our study thus should be less dependent on conversations with people. As a result, we decided to change the emphasis of the research from the interior of the home to a part that could be analyzed unobtrusively, and concentrated on the balconies, which, as our students put it, were "the screens of life." After choosing a common theme for our primary investigation, we started to elaborate on individual research focuses; for example, the activities for which different social groups use balconies, the kinds of materials people apply to cover the railings or make roofs, the types of balcony greenery, etc. In relation to our general theme, we settled on observation (supplemented with interviews and visual analysis) as our key method.

The example of the balcony could tell us a lot about the openness of a home - located between "private" and "public" realities, between "micro" and "meso" scales, it is both a stage for performing different activities and a material object which could be transformed (but only to certain degree). This case also illustrates Hansen's ideas of designing for specific and not faceless people and "leaving a margin for evoking one's own latent essence" ([1961] 2014: 8). The balcony is located on the edge, "inside outside" (Crowley 2002: 183) and it could be conceptualized as a "threshold space." According to Till Boettger, "thresholds open up spaces and organize transitions. At the same time, they are read as a part of the boundary and can be perceived as a barrier... [Threshold spaces] live in the sequence of what lies in the past, present, and future. This means: threshold spaces also live in the expectation of what is to come" (2014: 10). With this theoretical frame in mind, we started our collaborative ethnographic investigation.

Concentrating on the balconies of the Juliusz Słowacki housing estate went hand-in-hand with discussions about the key question that our study was going to answer. Five days after the start of the school, there were certain gaps in 
expectations: as tutors, we were more focused on the process (both learning and research, which I defined as an iterative practice), while students were struggling with outlining a clear result. We succeeded in reducing anxiety levels only after we had collected the materials and travelled to Warsaw, where the final presentation of the Urban Summer School was to take place. After two days of intensive analysis, we set up three questions, which we could answer based on the example of balconies on the Juliusz Słowacki housing estate: (1) How do open and closed forms coexist? (2) Where are the borders of human agency in relation to the idea of open form? and (3) In which ways does individuality shape collectivity? These topics were elaborated in a public presenatation and collective essay, which is planned to be published.

However, here I would like to step back and reflect a little on my personal experience of conducting fieldwork, both as a tutor and as a researcher with specific methodological interests. I was involved in organizing the school; therefore, I had certain organizational responsibilities - as tutors we were supposed to coordinate our groups and produce an outcome which would have either educational, scientific or social value (ideally - all of them). Therefore, we had to create both a friendly environment of mutual learning, to support the field stage at the organizational level (in the case of our group it meant preparing observation sheets, searching for potential storytellers who would agree to participate in group interviews, keeping track of field notes - all invisible technical and logistical work that accompanied ethnographic inquiries), and to provide expertise on specific topics. The tutor's obligation was to grasp and maintain the connections between each subject studied by participants and the collective topic of the group, as well as the links between the themes of the studios and the general framework of the school. Since the school itself was a process, this configuration constantly changed. It required adaptation skills, sensibility and a quick response to changes from us. Hence, the emotional overload, which is usually experienced by anthropologists in the field (Lofland, Snow et al. 2006: 27-28), was supplemented by the intellectual exhaustion from the need to keep in mind the individual trajectories of the participants and the overall picture of the school as a collective enterprise.

Engagement in the Urban Summer School was a challenge in terms of doing ethnographic research in a context which is both very similar and quite different from the one I have experienced on a daily basis. Questioning some obvious explanations and building on my background contextual knowledge were two parallel processes in my everyday reflections. As a sociologist I have been involved in a number of both quantitative and qualitative projects: therefore, I feel quite comfortable interviewing people in either Ukrainian or Russian. When it came to my Polish language skills, I felt less confident. Moreover, it was important not only to maintain a conversation and be focused on understanding, but also 
provide a translation into English (when I was interviewing people together with participants of my studio). Constant "switches between the modes" could result in the loss of quality of collected material and also demanded condensation of meaning immediately in the translation process.

I had visited the Juliusz Słowacki housing estate twice before the Urban Summer School - first during the Days of Modernism in 2017, and the second time while we were preparing the program for the school. These two tours around the neighborhood were guided by art historian Izabela Pastuszko, who was working on her $\mathrm{PhD}$ thesis on late Modernism in Lublin. One of the spatial solutions that was impossible to miss during those visits were the "serpentine" houses (wężowce) - three long, low buildings on numbers 2 and 12 Balladyny Street and 1 Skierki Street. One local activist has metaphorically described the façade of this "spine": "balconies are located asymmetrically and have their own purpose. They were like music, they prevented a full, boring harmony. The architecture here is an architecture of light. A balcony was an artistic element, it played with light and shadow" (fragment from an interview conducted by Paulina Paga. Cited in Lis 2014: 49). Long before we had started our collaborative project here, these buildings with strange, small balconies had caught my interest. They were a place where the inhabitants could manifest their creativity (for instance, while participating in "the best balcony-in-bloom", a competition organized annually by the estate's administration), where they could hide things or make them visible, where social interactions could take place and outsiders could be observed. The balcony is a space where people could be both at home and outside of it. They could serve both as thresholds and transitions.

\section{STUDYING THE "THRESHOLD SPACES" OF BALCONIES WITH DIFFERENT RESEARCH TOOLS}

Our group had just a few days to explore the reality of the Juliusz Słowacki housing estate. Taking into account the pressure of time, we decided to combine personal data-collecting with collective structured observation of the façade of the "longest" buildings from the first years of the estate's construction (Figure 2). All balconies are located on one side of the block and overlook a pedestrian zone. During four hours on 1 September, 2018 our group of eight persons managed to document all 281 balconies - we worked in pairs and split the selected building into observation sections. For this activity we used two observation lists. The first one had variables concerning the physical structure (questions about roofs, railings, furniture, decorations, etc.), while the other reflected the social life (number of people using the balcony, their age group, gender, activities). The collected data became key evidence for us in relation to the spatial changes and to both necessary 
and optional activities (Figure 3). For example, we documented that $48 \%$ of balconies were modified with the addition of roofs (which were not in the original project), and $66 \%$ of balconies were modified by either completely or partially enclosing the railings. Based on this observation, we could make a claim about the extent of participation in the transformation of the planned environment.

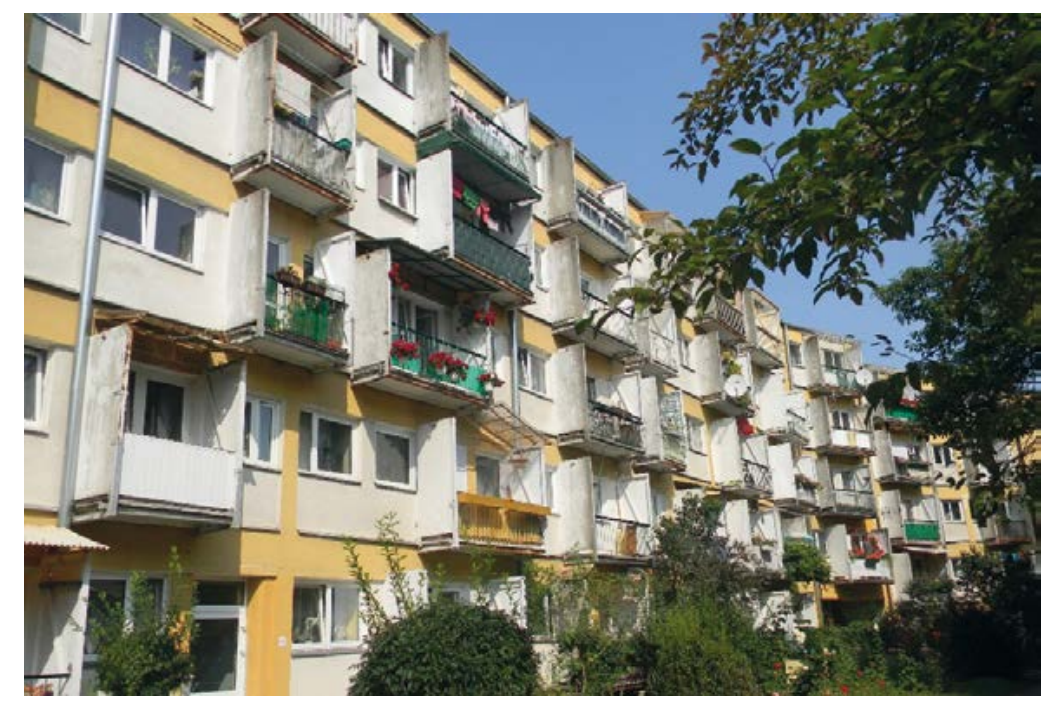

Figure 2. Observed "serpentine" building. Photo: Natalia Otrishchenko (2018)
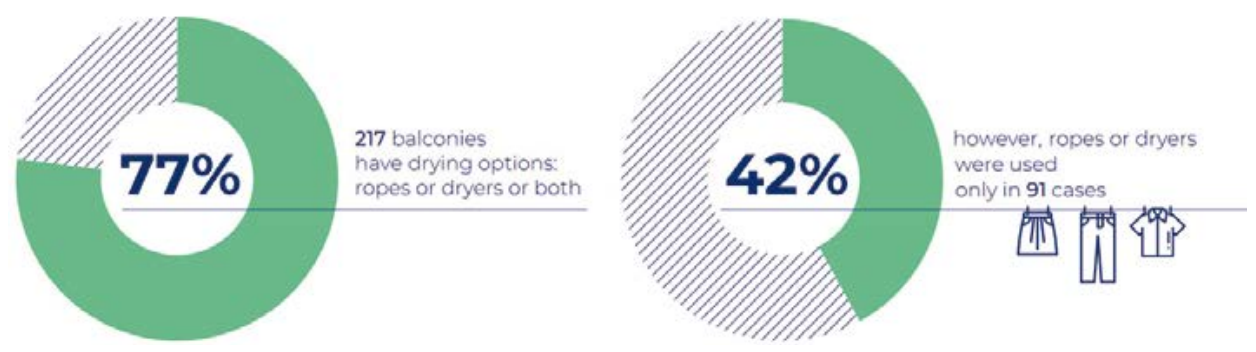

Figure 3. Summary of one of the activities related to balconies. Infographics: Oksana Nesterenko (2018)

To go beyond these numbers, some participants from our studio conducted individual observations according to their personal topics of interest, others engaged in a visual study aiming to grasp the daily rhythms reflected on the façade of our selected building and a few of us decided to focus on interviews - we 
managed to collect a total of 26 stories. Some of these interviews were rather short conversations, while others lasted for around 40 minutes. These dialogues were not recorded as they were informal and, for the purposes of our study, taking field notes was enough. Eight interviews were conducted inside apartments, so we also had a possibility to observe domestic spaces and take photos of the balconies from the inside. Furthermore, there were a few collective interviews with sequential translation from Polish into English. Overall, such an approach could be called "focused ethnography" (see Fuller 2017, Knoblauch 2005) as we carried out a very intense but short-term fieldwork with a specific clear-cut subject and to some extent concerted questions.

My entry point into the field was described at the beginning of this paper I was wandering around the neighborhood on one of the first days of school and collecting visual data. Balconies and pets (cats, dogs and artificial birds) was one of the topics I started to pay specific attention to. I saw a number of dogs and, at some point, there was a cat. My interest in taking photos of him did not go unnoticed: Anna, the owner of this pet, told me his name - Citek. She told me the whole geography of her cat's routes around the neighborhood, like the balcony with his favorite chair for sleeping or the areas where he hunted pigeons. Also, Anna showed me her balcony with flowers and her front garden. At some point, we started to chat about her balcony, and Anna's neighbor, an old man who was sitting on the bench nearby, added that during winter people use their balconies as fridges, and he had even made a special shelf for this reason. This small conversation with local people was my first encounter with the social reality of the balconies on the Juliusz Słowacki housing estate. It also gave me a few ideas for developing the project: the modification of the space for various purposes during different seasons, the relationships between the balcony and the area in front of it (especially for the ground floor), and animals as actors with their strategies of navigating in the space. Last but not least, I started to feel less anxious about my language skills, as people were willing to share with a researcher from another country. The fact that I was engaged in conversation in their language was a sign of respect that they appreciated.

Over the course of the week, the local inhabitants got used to the group of people who were visiting their estate every day. Although we were outsiders and our presence was very visible, we were treated with interest and the inhabitants showed a willingness to help. One of the pleasant and quite unpredicted observations we made was the "openness" of the people. Participants of my studio admitted that they had not expected local people to be ready to talk. I assume that this was the result of our position as participants of an international educational project - the school was advertised in local media and around the neighborhood area, so inhabitants of the Juliusz Słowacki housing estate knew about us and they 
were prepared for our presence. We outlined our goals as educational: therefore, people did not feel objectivised by our "studying" gaze. As the school is based on the principles of participation, we aspired to collaborate with local residents, rather than turn them into "research subjects."

Our interest in balconies was a very comfortable and safe topic for entering the field - they were a visible part of personal space, and by talking about them it was possible to make conversation about a more intimate reality of home. Therefore, starting from the balcony, we tried to understand how it was connected with the rest of the apartment: Is it perceived as an additional room or as a space "outside"? How "active" is this zone? Mental maps were quite helpful in finding the answers. For instance, Figure 4 shows two drawings made by children who participated in the summer camp. Both of them drew balconies represented as an integral part of the children's homes. In the picture on the left, the balcony (lower right corner) takes up as much space as any other room, and the drawing on the right, which depicts the apartment as a sequence of transitions between the rooms, has the balcony (upper right corner) as the final point of the route through the home. The left-hand image shows the experiences of each room as separate ones, while in the image on the right there is a system of links. However, in both cases the children perceive the balcony to be an integral part of their home. The same conclusion could be made for adults: in one of the drawings received from the parents (Figure 5) the balcony is depicted as a zone of leisure. It is one of the favorite spaces in the apartment (marked with a heart) and more active during weekends (red arrows). These findings correspond to the ones made by Ewa Klima, who was researching mass-housing estates in Łódź: one of her narrators, an old lady, called her balcony "the third room" (2012: 30). Despite the fact that we received just a few drawings, this method is quite promising for the study of spatial experiences and practices, when both content and composition could provide insights about the relations between people and their apartments. It is also helpful for situations when the language issue could become an obstacle - together researchers and local inhabitants could develop a set of pictograms (which itself could be a source for a cultural study) to depict various practices and emotional reactions.

Another part of visual analysis is connected to the photos. Sometimes I asked permission to take a picture of the balcony when I saw people there, and it was the beginning of conversation, and sometimes photos were taken after the interview. For example, I approached a lady who was tending her flowers. We were talking about her life in the apartment on the ground floor and activities connected with the balcony. When I asked her whether I could take a picture, she agreed but removed the laundry and closed the curtains before I did it. This small episode reveals a clear-cut borderline between "private" and "public" realms - the point when a balcony from everyday reality is moved into a fixed image, it receives 


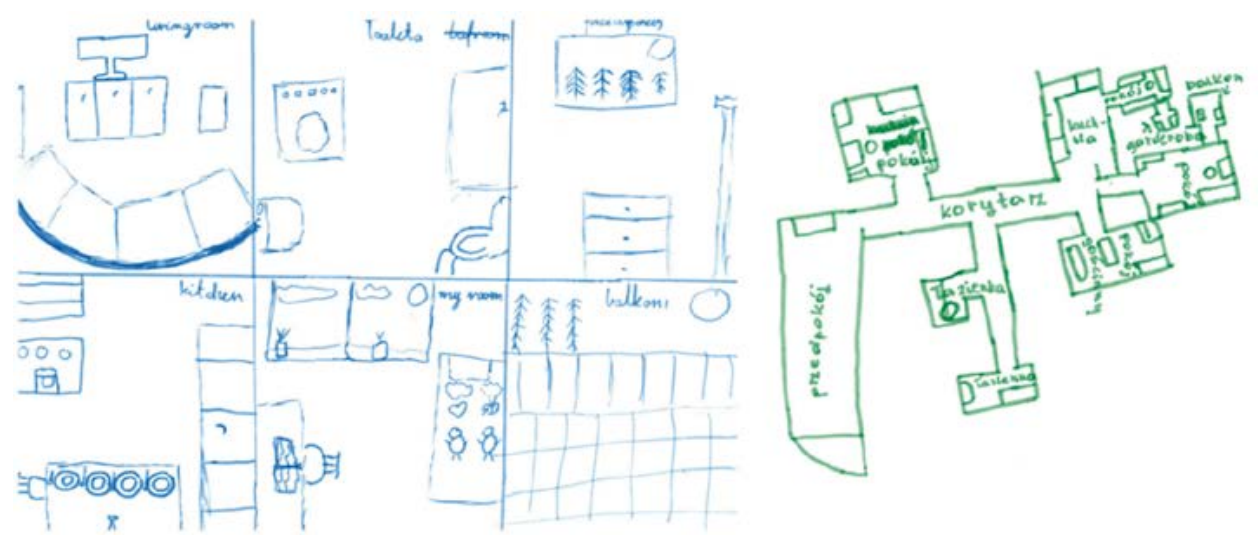

Figure 4. Maps of apartments, drawn by two girls age 9 .

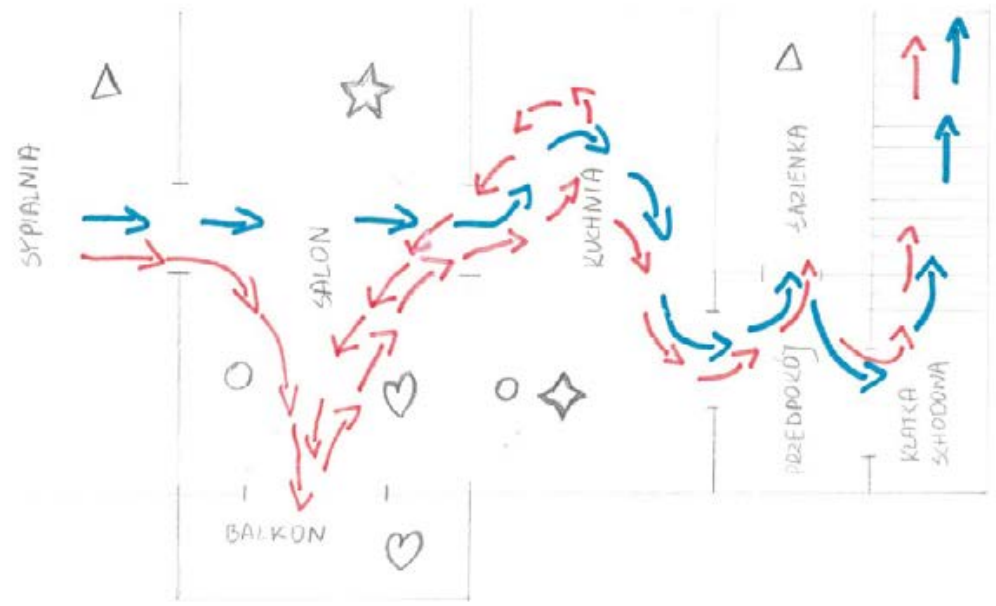

Figure 5. Picture, drawn by female, age 44, mother of a girl who participated in the summer camp.

a representative function. Hence, it had to be cleared of the layers of everydayness (such as laundry) and detached from the personal space of the apartment with curtains. Therefore, balconies work as thresholds in both ways: they open spaces but also close them by separation.

At some point our group had collected a lot of materials that documented the façade, so to complement the story about the relation between inner and outer spaces we needed a view from the inside (Figure 6). A small request to take 
a picture from the balcony was an important strategy for starting a conversation with local inhabitants. I asked people who I saw on balconies to take the photo with my camera looking from the position where they were standing. The majority, however, invited me into their apartments and offered to let me take the picture myself. Thanks to such hospitality I gathered rich visual materials, but also conducted interviews with these people inside their apartments.

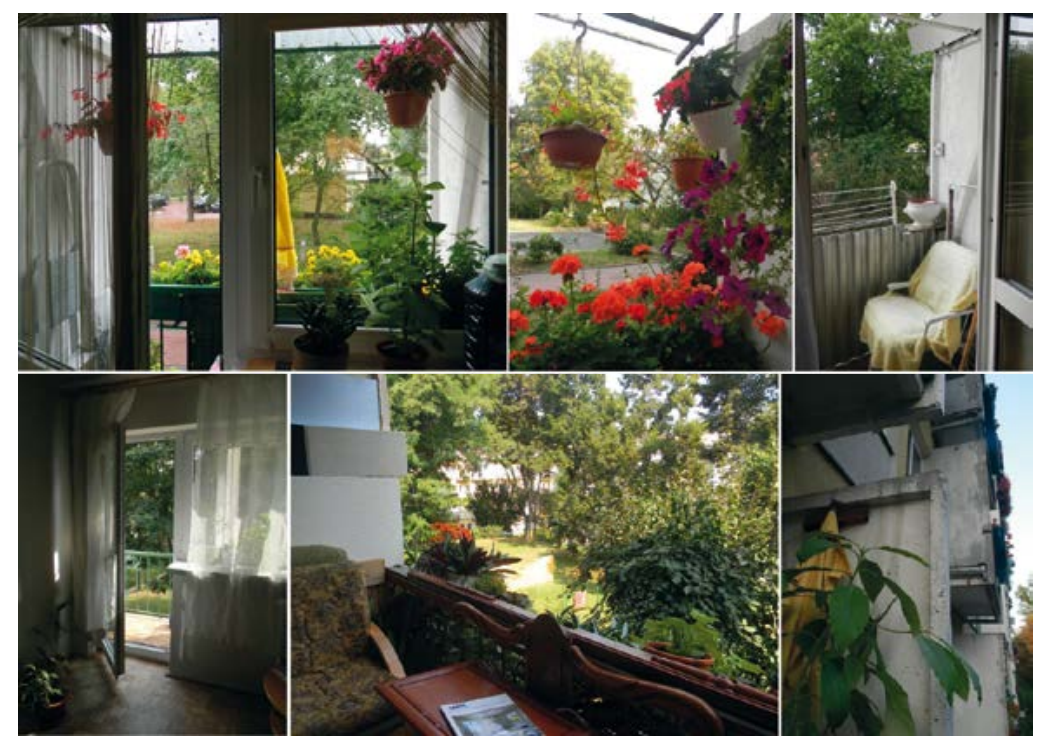

Figure 6. "Inside outside" spaces of balconies of the Juliusz Słowacki housing estate.

Photos: Natalia Otrishchenko (2018)

It was the way I met Magda. She is a former teacher who has lived in her apartment since 1966. For many years she was a winner of "the best balcony-inbloom" competition - she showed me her certificates and prize books. However, since her husband passed away a year ago, she has visited her relatives more often and does not have time to tend to the flowers. Now she uses the balcony as a place to observe the neighborhood (actually, it was the way we saw each other), enjoy the greenery, drink coffee and dry her laundry. There is a chair and clotheslines there. Cups were usually located on the windowsill. After I took photos of the balcony and we discussed the specifics of "the best balcony-in-bloom" competition, she gave me information she had previously prepared for a person who was studying this area. For instance, Magda told me that the main entrances to the block and balconies are from the inside of the neighborhood to provide inhabitants with a feeling of calmness and safety. The irregular location of the balconies aims "to 
disrupt the monotony" and their side walls give intimacy although people can still see each other. Sometimes these side walls are located in the centre of the window, but, as Magda pointed out, it was not the fault of the architect ${ }^{8}$ but of the builders. Also, she said that many rooms are long and narrow, so it is difficult to organize the space. However, people have the possibility to re-arrange the inner structure of the apartment. Her neighbour, for instance, wanted to have few rooms but larger ones. She herself supported the idea that more rooms is a better option, even if they are smaller, as "everyone has a room to close themselves away from the outside." As for disadvantages, the woman mentioned the small, dark kitchen but she knew it had to be cheaply and quickly constructed. Magda dislikes all of the balcony modifications. She would like to see all the roofs and additions removed, as it creates "the feeling of slums and destroys the view of interesting architecture. There is no unity."

This case is a great example of both the possibilities and limitations of the "Open Form" - the inner structure of apartments allows people to make spatial rearrangements according to their current needs; however, specific aspects of the reality of home, like the location of the kitchen, are fixed. Magda's dissatisfaction with the redesigned balconies also illustrates the inner tension which characterizes the logic behind the individual both "finding himself in the collective" and "indispensable in the creation of his own surroundings": inhabitants of the Juliusz Słowacki housing estate adapt these semi-private spaces to their personal needs and lifestyles, but the spatial perception of the façade as a unity is lost.

The balconies create a link between the personal space of home and the shared space of the neighborhood. It is especially strong in the case of the ground floor, where a balcony could be extended into the space of a small garden in front of it. One such balcony belongs to the family who used to win "the best balcony-inbloom" competition: 80-year-old Adam, former policeman, and his wife Irena. This space was surrounded by plants and flowers and it was my great fortune to see the man behind this blooming curtain. I approached him with a request to take a photo of the view from his balcony. He called to his wife, and she agreed to let me into the apartment to see the balcony from the inside. The couple is retired and they have lived in this apartment for fifty years. Adam was sitting on his "throne"a nice, big chair covered with artificial fur. He said he uses it for "reading, resting, and thinking." He likes to observe the street from this point and he can listen to the Holy Mass from here, as the church is nearby. For him, as a Catholic, it is quite important. He is happy to live on the ground floor. When he was about to get an apartment (in his late 20s), he was already thinking ahead to when he would be retired and now there is no need to use the stairs.

Agata also lives on the ground floor with her husband and dog Pimpek - her children have their own families and live separately. I heard barking and decided 
to take a picture of the pet on the balcony - a question about the dog started our conversation. She used to live in the older part of Lublin, but moved to the Juliusz Słowacki housing estate 50 years ago. For a family with two kids it was a nice choice, she said. Her husband, who is in his 80 s, spends a lot of time on the balcony, simply sitting there or reading. She herself uses this space for watering the flowers and drying laundry. She tries to put it on two small lines in the corner, as the hanging clothes could "spoil the view." Agata says she is happy to live on the ground floor: when she was young, her children would play right in front of her apartment, so she could easily watch them, and now she is happy not to use the stairs. She also tended the small garden in front of her balcony. At the end of our informal interview, I asked her if I could take a photo of her balcony - it was the only time when a person agreed to do it themselves. Similar to mental maps, this method could be used on a larger scale and, therefore, provide rich visual data on specific "local gaze" and insiders" perspectives. For example, Ewa Klima used a method which she called "collaborative photographs," when respondents were asked to take pictures as part of the topic "My dwelling in a block of flats" (Klima 2012: 31). It was applied by Krista Harper in participatory "photovoice" projects about the environment and health of Roma people in Sajószentpéter, Hungary (Harper 2013: 81-88). Despite the fact that the discussion of the methodological, technological, ethical, and legal specifics of this method requires a separate review, I do believe it could be a very productive tool for an ethnographic encounter with personal realities.

Two families we met before - Adam's and Agata's - have similar strategies in terms of their activities and discursive justifications. They have extended their home to the area outside of the apartment. This gesture speaks not only about the semi-privatization of spaces near the house, but also of the readiness to take responsibility for the common good. The narrators spoke about their eagerness to make their home "beautiful" not only for themselves but also for people who pass by. They invest their time and resources in small gardens and greenery on the balconies in order to create a place where it would be nice to live. For the most part, such flower beds are organized by the families who live on the ground floor, but there may be exceptions.

Spending time on the balcony allows people to be simultaneously in the personal space of home and in shared spaces: thus, Adam could listen to Holy Mass and Agata could keep an eye on the kids without leaving their home. The "threshold" nature of these spaces allows people to use them as observation points and places of rest, where it is possible to hide. It creates possibilities for social interactions - I observed two ladies who were talking while on different sides of the balcony. They are neighbors: one from the ground floor and one from the second floor (she was standing on the street in front of her friend). The lady who lives on the ground 
floor said that she often used the balcony as a place for conversations: she had two chairs and a table there and could even add an extra chair to accommodate all of her friends on the balcony. According to the observations our group made, $20 \%$ of the documented balconies have furniture (one or two chairs, tables, shelves, etc.), and in almost half (45\%) it was impossible to draw any conclusion about either the presence or absence of any furniture because they were enclosed. This furniture can indicate the function of the balcony as an extension of home - it could be an extra living room, dining room, work space or even kitchen (I saw a man who was peeling potatoes - he also invited me to take a picture from his balcony). Along with this, the social function also manifests itself in the fact that it is used as a place for talking on the mobile phone - an activity which we observed a few times.

At the same time, the amount of time people spend on balconies depends on the season, time of day and week, and weather conditions. Our explorative study took place at the end of August and beginning of September, predominantly during the day, when it was warm and sunny. Therefore, observations on social activities, related to the balconies, have to be treated with caution. Depending on the season, "the profile of the balcony" could also change, as was already mentioned by Anna's neighbor, who turned his balcony into a fridge during the winter.

\section{CONCLUDING REMARKS}

The balcony could be described as a relational concept, a material and symbolic space which is shaped by experiences and aesthetics, located "between memory and nostalgia for the past, everyday life in the present, and future dreams and fears" (Blunt and Varley 2004: 3). As a threshold it constitutes both the space inside and outside, either a blurred or clear-cut border between home and the world outside. The in-betweenness of the balcony defines its qualities - it is either an extension of the home or a place beyond the borders of privacy. It is determined both by its own materiality and by the activities that modified it: from enclosing the space with opaque plastic and building a roof to growing flowers or installing shelves and dryers. In the case of the Juliusz Słowacki housing estate, there is also the figure of the author - the architect Oskar Hansen, who himself believed in an active user. Our explorative study only scratched the surface - we observed the reality but did not explain it: What resources do people use to shape their balconies? Why and how did the changes happen? What is the interplay between different actors: those from "the inside," like local inhabitants, and from "the outside," such as politicians and activists from heritage protection? What are the individual and collective strategies? How is the balcony related to "the home"?

This paper has discussed a number of research methods which could be used in an urban environment in order to grasp the everydayness of space production. 
Some of them are unobtrusive (like observation and analysis of photographs taken by the researchers themselves), and they can provide us with a general overview. The others are mediated either by language or by other means. These methods could be combined in one strategy with "focused ethnography" in order to provide insights on questions related to people's interactions with the spaces. Especially promising tools are mental mapping and participatory photography, both of which provide researchers with visual and culturally rich data.

The project on "thresholds" was limited both in time and in space. It was conducted as a part of the Urban Summer School and had educational aims. However, the very formulation of the research questions was a success - in a diverse group we managed to find a common denominator, which was not imposed but developed by the group. For me personally it is the key outcome in terms of a process-oriented approach toward the research.

\section{NOTES}

1 All names have been changed in order to protect the privacy of the narrators.

2 The school was organized by the National Institute of Architecture and Urban Planning (Poland) in cooperation with the Center for Urban History of East Central Europe (Ukraine) and financed by the Ministry of culture and national heritage (Poland). More information about it can be found at: http://niaiu.pl/en/uss-en/ (as for 20 June 2019).

3 The Hansens constantly contrasted the Open Form to the Closed Form - this dichotomy is crucial for their definition.

4 Just to mention the famous and widely cited book "The Death and Life of Great American Cities" by journalist and urban activist Jane Jacobs, which was published in 1961, the same year as the Hansens' "Open Form Manifesto."

5 More information about this initiative can be found here: http://www.team10online.org/ (as for 20 June 2019).

6 Together with Tomasz Fudala I was tutoring a group of six young professionals, and two thirds of them had an architectural background. The participants of our studio were Arpenik Atabekyan (anthropologist and literary scholar from Armenia, who was conducting her M.A. in Gender studies in the CEU, Budapest), Arta Gashi (urban planner from Kosovo, with MSc in Architecture from the University of Pristina), Tatiana Gurduza (architect from Moldova, graduated from the BME, Budapest), Wu-Lung Lu (architect from Taiwan, master student of the Bergen School of Architecture), Ievgenii Obraztsov (artist and designer, graduated from Prydniprovska State Academy of Civil Engineering and Architecture, Ukraine), Aleksandra Turowska (anthropologist from Poland, working on her PhD in the Adam Mickiewicz University of Poznan).

7 The program was organized by the National Institute of Architecture and Urban Planning based on the experience of educational initiatives held by the Center for Urban History of East Central Europe. More information about this initiative can be found here: http://www.lvivcenter.org/en/publichistory/educational-projects/2743-18-08-26-lublinschool/ (as for 20 June 2019).

8 Magda did not provide Hansen's name, just "an architect" - it was quite common among the estate's inhabitants. 


\section{REFERENCES}

Blunt, A., \& Varley A. (2004). Geographies of Home. Cultural Geographies, 11(1), 3-6. https://doi.org/10.1191/1474474004eu289xx

Boettger, T. (2014). Threshold Spaces: Transitions in Architecture: Analysis and Design Tools. Basel: Birkhäuser. https://doi.org/10.1515/9783038214007

Coudroy de Lille, L. (2013). Le logement en République populaire de Pologne: du «déficit» à la «crise», Le Mouvement Social, 245, 109-122. https://doi.org/10.3917/ lms.245.0109

Crowley, D. (2002). Warsaw Interiors: The Public Life of Private Spaces, 1949-65. In D. Crowley \& S. Reid (Eds.). Socialist Spaces: Sites of Everyday Life in Eastern Bloc (pp. 181-206). Oxford: Berg. https://doi.org/10.5040/9781350057692

De Carlo, G. ([1969] 2007). Architecture’s Public. In P. B. Jones, D. Petrescu \& J. Till (Eds.). Architecture and Participation (pp. 3-22). Abingdon: Spon Press.

Fuller, M. (2017). Great Spatial Expectations. On Three Objects, Two Communities and One House. Current Sociology Monograph, 65(4), 603-622. https://doi. org/10.1177/0011392117694071

Gubrium, A. \& Harper, K. (2013). Participatory Visual and Digital Methods. Walnut Creek: Left Coast Press.

Gola, J. (2005). Towards Open Form. Warsaw: Foksal Gallery Foundation; Frankfurt: Revolver.

Hansen, O. \& Hansen, Z. (1961). The Open Form in Architecture - the Art of the Great Number. In O. Newman (Ed.). CIAM '59 in Otterlo (pp. 190-191). Stuttgart: Karl Krämer Verlag. Reprinted in Kędziorek A. \& Ronduda L. (Eds.) Oskar Hansen Opening Modernism: On Open Form Architecture, Art and Didactics (pp. 7-9). Warsaw: Museum of Modern Art.

Klima, E. (2012). Geografia domu - mieszkanie w bloku. Folia Geographica SocioOeconomica 12, 19-36.

Knoblauch, H. (2005). Focused ethnography. Forum Qualitative Sozialforschung / Forum: Qualitative Social Research 6(3), Art. 44. Available at: www.qualitativeresearch.net/index.php/ fqs/article/view/20 (as for 30 December 2018).

Lis, R. (Ed.) (2014) Lokatorzy. Warszawa: Stowarzyszenie Praktyków Kultury.

Lofland, J., Snow, D. A., Anderson, L. \& Lofland, L. H. (2006). Analyzing Social Settings: A Guide to Qualitative Observation and Analysis (4th Edition). Wadsworth Cengage Learning.

Odyjas, E. (2014). Teoria i Praktyka Formy Otwartej Oskara Hansena. Zeszyty Naukowe Politechniki Śląskiej. Seria Architektura 54, 127-136.

Rudofsky, B. (1964). Architecture without Architects. An Introduction to Non-pedigreed Architecture. New York: The Museum of Modern Art.

Stanek, L. \& van den Heuve, D. (2014). Introduction: Team 10 East and Several Other Useful Fictions. In Stanek L. (Ed.). Team 10 East: Revisionist Architecture in Real Existing Modernism (11-33). Warsaw: Museum of Modern Art in Warsaw.

Sulikowska, A. (2015). Teoria Formy Otwartej i Linearny System Ciąły. O poszukiwaniach założeń koncepcji Oskara Hansena w obecnej rzeczywistości przestrzennej Poznania. Refleksje 11, 95-110. 
Natalia Otrishchenko - sociologist, research fellow at the Center for Urban History of East Central Europe (Lviv, Ukraine). She obtained a PhD with a focus on "methodology and methods of sociological research" from the Institute of Sociology at the National Academy of Sciences of Ukraine. Natalia was a tutor and later coordinator of the Urban Summer Schools "Visions and Experiences," on behalf of her institution she was involved in the organization of the Urban Summer School "Open Form." She participated in a number of international research projects: "Region, Nation, and Beyond" (University of St. Gallen), "Memory of Vanished Populations" (Lund University), "Historical Cultures in Transition" (Collegium Civitas). Her area of academic interests includes methods of sociological research, urban sociology, spatial and social transformations after state socialism. 